\title{
Dynamic of Components Leachate from Experimental Fertilizers in Leaching Test
}

\author{
Tomasz Ciesielczuk ${ }^{1 *}$, Joanna Poluszyńska², Agnieszka Szewczyk², \\ Czesława Rosik-Dulewska ${ }^{3}$, Monika Sporek ${ }^{4}$ \\ 1 Department of Land Protection, Opole University, Oleska Str. 22, 45-052 Opole, Poland \\ 2 Institute of Ceramics and Building Materials, Oswiecimska Str. 21, 45-641 Opole, Poland \\ 3 Institute of Environmental Engineering of the Polish Academy of Sciences, Skłodowskiej-Curie Str. 34, \\ 41-819 Zabrze, Poland \\ ${ }^{4}$ Department of Biotechnology and Molecular Biology, Opole University, Kominka Str. 6a, 45-035 Opole, \\ Poland \\ * Corresponding author's e-mail: tciesielczuk@uni.opole.pl
}

\begin{abstract}
Organic matter contained in the waste of food industry or occurring in the households, in the absence of contamination with other kind of waste, may be used to create a "fertiliser", which could be even reused in the organic production of arable crops. Particular attention is drawn to the fertilisers which may be applied in the case of amateur cultivation of pot plants and in the allotment gardens. The paper presents the results of research regarding the dynamics of the release of nutrients from tablets created with the help of encapsulation of the mixture manufactured from solvent extraction waste of coffee (SCG), modified by the ash obtained from low temperature burning of biomass. In this study, the mixture was determined as a fertilizer. Collagen, polyvinyl acetate, polyvinyl alcohol, shellac as well as sodium water glass have been applied as testing membranes in order to slow down the elution of the components from a fertilizer into solution. The durability tests have been carried out according to PN-EN-13266 standard over 118 days at the temperature of $25^{\circ} \mathrm{C}$. The obtained results indicate significant differentiation with regard to the leaching of nutrients and organic matter from the tablets depending on the applied membrane. Strong inhibition concerning leaching of the components through membranes and from shellac and polyvinyl acetate has been observed. The remaining membranes did not inhibit the leaching of nutrients in the long-lasting manner; however, even they may be applied in the agricultural practice.
\end{abstract}

Keywords: nutrients, slow-release fertilisers, leaching, solvent extraction spent coffee grounds, sustainable fertilisation.

\section{INTRODUCTION}

In the era of greater care towards the high quality of crops, sustainable agriculture is becoming an essential kind of cultivation of plants in the world (Chang et al. 2010).

Such crops require fertilisation, which on the one hand should provide optimal amount of nutrition elements, improve the water-air relations in soli and should not endanger the quality of underground water. The organic fertilisers are preferable, as they not only act slowly, but also increase the water capacity of soils and positively influence the absorbent complex.

The organic substance contained in the waste of food industry is directed to the production of feed or biogas installations; however, they could be used as a source of valuable nutrients in the plant production. The volume of waste per capita in Poland is relatively insignificant and in 2016 it amounted to $303 \mathrm{~kg} / \mathrm{capita} / \mathrm{year}$, while the average of $28 \mathrm{EU}$ countries at the same time equalled $481 \mathrm{~kg}$, up to $50 \%$ of which may constitute the biodegradable waste (Eurostat, Statistical Yearbook 
of Environmental Protection 2017). The selective collection of fractions of biodegradable waste carried out at the source creates a possibility to obtain the high quality fertiliser. It also concerns the solvent extraction waste (SCG) occurring after preparation of drinks from coffee beans. This waste is produced in substantial amount due to growing consumption of this beverage that started to be consumed over one thousand years ago (Mussatto et al. 2011). The annual consumption of coffee in Poland is growing and it currently approximates $3 \mathrm{~kg} /$ capita/year. However, this amount is several times lower than in the Scandinavian countries. In the case of households, the produced waste is placed in the containers for mixed waste or goes to the biodegradable fraction containers.

SCG material contains a wide range of valuable organic compounds, among others consisting of: tannin, cellulose, hemicellulose, polyphenols and organic acids, and thus they are used to produce biocarbon, for composting as a sorbent and to obtain biodiesel; however, these are costly technologies forcing the consumption of substantial amounts of fossil fuels (Caetano et al. 2014, Pujol et al. 2013). An alternative and cheap way to reuse the solvent extraction waste of coffee (SCG) is its processing into fertiliser. After mixing it with ash from the combustion of biomass, this waste may be manufactured autonomously, which not only allows saving financial resources spent for fertilisers, but also to lower the mass of deposited biodegradable waste. In this way, the non-contaminated organic matter may constitute a valuable source of nutrients for organic crops. Such fertilisers manufactured at the place of its usage are cheap because the costs connected with its purchase and transport are not incurred. The quality of fertilisers obtained in such way is high, and moreover - on the contrary to sewage sludge and bottom sediments - they do not contain excessive quantities of heavy metals, which enter the food chain (Lopes et al. 2011, Strzebońska et al. 2015). The fertilisers made up of the solvent extraction waste of coffee (SCG) could be applied in the case of organic crops governed by the regulation of the European Commission No. 354/2014 as of April $8^{\text {th }} 2014$, (amending the regulation concerning the change and correction of the regulation (WE) no. 889/2008 establishing detailed implementation principles regarding the regulation of the Council (WE) no. 834/2007) on ecological production and marking of ecological products with regard to ecological production, marking and control.

The objective of this study was to determine the release rate of nutrients and organic matter from encapsulation of tablet fertilisers, manufactured on the basis of solvent extraction waste of coffee (SCG) modified with the help of the ash obtained during low-temperature thermal conversion of biomass. The tablet fertilisers containing an identical composition as the series of K10 fertiliser have been prepared in order to be used in the study. (Ciesielczuk et al. 2016), but the membrane slowing down the action of fertiliser in soil has been modified.

It should be stressed that the examined membranes are tested for the first time, and the data regarding the usage of the means prepared in such way which support the crop were not described in the available literature.

\section{MATERIALS AND METHODS}

The solvent extraction waste (SGG) obtained after the preparation of coffee beverage (under the pressure of 15 bar) as well as the ash coming from thermal conversion of oak biomass (wood together with bark) were used in the leaching test (Ciesielczuk et al. 2014). In order to obtain the ash, the oak wood was combusted together with bark at the temperature of $600^{\circ} \mathrm{C}$ for 3 hours in the open hearth, and then the material obtained in such way was burned at the same temperature for 1 hour in the muffle furnace (Xiao et al. 2011). The ash was passed through a sieve with $2 \mathrm{~mm}$ mesh, and then was dried into constant weight.

After conducting initial research, 6 series of tablet fertiliser with identical composition as the series of K10 fertiliser have been prepared for the experimental purposes (described by Ciesielczuk et al. (2016). The fertiliser tablets were covered by membranes, having differentiated composition, the task of which is to slow down the elution of nutrients and organic matter into the soil solution (Table 1).

The way in which the tablet fertiliser is manufactured was precisely described in the publication of Ciesielczuk et al. (2014).

The tablet fertilisers were manufactured from identically prepared SCG coming from the same sort of coffee and the same sort of ash. All the examined tablets were covered with 2 layers of membrane in order to slow down the leaching 
Table 1. Used membrane types for K10 fertilizer

\begin{tabular}{|c|l|c|l|}
\hline Type & \multicolumn{1}{|c|}{ Membrane } & Type & \multicolumn{1}{c|}{ Membrane } \\
\hline KR & Fish collagen (fish bladder) & OW & Polyvinyl acetate \\
\hline KK & Skin collagen (swine skin) & SZ & Shellac \\
\hline PW & Polyvinyl alcohol & SW & Sodium silicate (water glass) \\
\hline \multicolumn{2}{|r|}{ C-Control samples (without membrane) } \\
\hline
\end{tabular}

of nutrients from a fertiliser into soil solution. The second layer of membrane was applied after a complete drying of the first layer. The control sample constituted the tablet fertilisers K10 without membrane. In such manufactured tablet fertilisers marked element involved the content of organic substances with the help of weighing method after roasting in the temperature of $600^{\circ} \mathrm{C}$ for 3 hours. The $\mathrm{pH}$ value was measured for the tablets ground in the hammer mill, using solutions of $\mathrm{H}_{2} \mathrm{O}$ and $1 \mathrm{M} \mathrm{KCl}$ in the ratio of $1: 10$ $(\mathrm{v} / \mathrm{v})$. The content of total organic carbon (TOC), total nitrogen, hydrogen and sulphur was marked in infrared by CHNS Vario Macro Cube analyser made by Elementar company. The content of phosphorus was measured with titration method after mineralisation with sulphuric acid. The content of sodium, potassium and calcium was determined in the wet mineralisates by means of the FES method with the use of BWB XP apparatus. The content of magnesium and heavy metals such as: zinc, copper, lead, nickel, chromium, cadmium was determined by spectroscopy of atomic absorption with the use of iCE Thermo 3500 apparatus after microwave wet mineralisation in aqua regia by the $\mathrm{w}$ Mars- $\mathrm{X}$ apparatus.

In order to determine the release of nutrients, the water extracts have been carried out according to PN-EN-13266 standard. These water extracts were examined after: 24 hours, 3 days, 1 week, and then in weekly intervals. The following elements have been marked for the obtained extracts: $\mathrm{pH}$ value, electrolytic proper conductivity (EC) by the electrometric methods, content of total organic carbon (TOC) and total nitrogen (TN) by the detection of non-dispersive absorption in infrared (NDIR), after mineralisation of the sample in the temperature of $850^{\circ} \mathrm{C}$. The content of phosphate and ammonium ions, nitrite and nitrate ions, sulphate, potassium and calcium ions was determined by means of IC ion chromatography method with Metrohm 850 Professional IC AnCat - MCS ion chromatograph. The obtained results are an average from three independent extraction experiments.
The water extracts from the examined fertilisers have been made under cover at the temperature of $25^{\circ} \mathrm{C}$ without the access to light in the water of class 3 . The ratio of fertiliser to water was $1 / 50(\mathrm{~m} / \mathrm{m})$. In order to conduct the physicochemical analysis, the obtained extracts were filtered through a quartz wadding, and the experimental containers were immediately supplemented with a precise amount of fresh water.

\section{RESULTS AND DISCUSSION}

\section{Characteristics of tablet fertilisers}

All discussed fertilisers contain a significant share of SCG with stabilising addition of ash from biomass, which enables their application in the case of light soils, without the concern for decreasing the content of organic carbon and nitrogen in the soil, which takes place in case of fertilising with sole ash from biomass (Demeyer et al. 2001). The proposed type of tablet fertiliser $\mathrm{K} 10$ is an example of mineral-organic fertiliser, which is the most beneficial for cultivated plants. (Ludwig et al. 2011). Comprehensive fertilising, providing plants with necessary components, in particular $\mathrm{N}, \mathrm{P}, \mathrm{K}, \mathrm{Ca}$ and $\mathrm{Mg}$, for a longer period of time, which takes place in the case of the described tablet fertilisers constitutes a basis for sustainable fertilising in order achieve optimal yield (Cole et al. 2016).

Despite the application of identical components to make the tablet core and identical way of placing matrices, the examined tablet fertilisers are characterized by different mass. It is the result of the layer thickness connected with the membrane slowing down the release of nutrient components and its nature itself - among others, deep penetration of pores regarding the core of fertilising tablet, viscosity and the content of organic substances. The highest mass was recorded for a fertiliser with OW membrane, whereas the lowest one was recorded for a type of PW membrane. The membrane thickness may influence the total content of nutrients, which is available 
for plants after the application of fertiliser. It is particularly important in the case of the application of fully biodegradable organic matrices (KR, $\mathrm{KK}$ and SZ). Moreover, the membrane slows down the moistening process of the tablet core. The tablet fertilisers without a membrane tested in this study, under the conditions of insufficient soil moisture may therefore act faster, which may be essential at the beginning of the vegetation period. Particularly important are also the drought periods, which significantly limit the disintegration process of fertiliser tablets in the surface (Table 2). The K10 fertiliser is a universal material with neutral $\mathrm{pH}$, which can be applied for the majority of pot and garden plants.

In the case of SW-type tablets, the membrane significantly increases the $\mathrm{pH}$ value (up to the value above 10) as well as the value of proper electrolytic conductivity (almost 3700 $\mathrm{uS} / \mathrm{cm})$. It may have a negative impact towards the growth of plants, especially in the case of seedlings. Such conductivity is as high as granulates made of sewage sludge and coal ash (Rosik-Dulewska et al. 2008).

Pure SCG waste is characterized by acidic $\mathrm{pH}$; however, in the mixture with alkaline ash, the obtained $\mathrm{pH}$ values were close 7 . The examined series of fertilisers (except the above-mentioned fertiliser of SW type) were characterized with the value of $\left(\mathrm{pH}_{\mathrm{KCl}}\right)$ from 7.06 up to 7.98 and $\left(\mathrm{pH}_{\mathrm{H} 2 \mathrm{O}}\right)$ from 7.05 up to 8.15 . The only factor influencing the $\mathrm{pH}$ value is the kind of the applied membrane, and stability of this $\mathrm{pH}$ value is an important fea- ture increasing the buffering of soil environment. The results of $\mathrm{pH}$ value for SCG are confirmed by other authors (Kim et al. 2014). High value with regard to electrolytic conductivity of SW type is worrying; however, disintegration of the fertiliser delivered in the form of a tablet is going to be very slow, which prevents a sudden release of components into the soil solution. However, it should be kept in mind that significant salinity (occurring even locally), may be dangerous for plants. The remaining fertilisers are characterized by a lower salinity $(1158-1845 \mathrm{uS} / \mathrm{cm})$, and therefore it is predicted that there is going to be no toxic influence on the growth of seedling.

The examined fertilisers, due to significant share of SCG, are characterized by a high content of organic substances, unprecedented in other kinds of natural organic fertilisers such as compost, manure or slurry (Boruszko 2011, Cesaro et al. 2015). Its marked quantity negatively correlates with the number of ash from biomass applied in the process of manufacturing of fertiliser (Ciesielczuk et al. 2016). The applied membranes slightly decrease the content of organic matter (nevertheless, it still exceeds 90\%). The exception is the SW type in which non-organic membrane is made from water glass causing a substantial decrease in the value of this parameter, reaching up to $77.5 \%$ ). The composition of organic substance contained in SCG constitutes mainly of polysaccharides, proteins and fats, which guarantees a slow release of nutrients from disintegrating organic matter (Ballesteros et al. 2014;

Table 2. Basic characteristics of the investigated fertilizers $(n=3)$

\begin{tabular}{|l|c|c|c|c|c|c|c|}
\hline \multicolumn{1}{|c|}{ Specification } & $\mathrm{C}$ & $\mathrm{KR}$ & $\mathrm{KK}$ & $\mathrm{PW}$ & $\mathrm{OW}$ & $\mathrm{SZ}$ & $\mathrm{SW}$ \\
\hline Mass of fertilizer $[\mathrm{g}]$ & $7.76(0.23)$ & $7.61(0.47)$ & $7.45(0.45)$ & $6.39(0.13)$ & $12.54(0.35)$ & $6.42(0.19)$ & $7.53(0.13)$ \\
\hline Reaction $\left(\mathrm{pH}_{\mathrm{kCC}}\right)$ & $7.32-7.58$ & $7.42-7.50$ & $7.06-7.14$ & $7.96-7.98$ & $7.08-7.09$ & $7.52-7.58$ & $10.31-10.35$ \\
\hline Reaction $\left(\mathrm{pH}_{\mathrm{H} 2 \mathrm{O}}\right)$ & $7.08-7.45$ & $7.05-7.09$ & $7.10-7.21$ & $7.91-8.15$ & $6.99-7.07$ & $7.60-7.72$ & $10.42-10.46$ \\
\hline $\mathrm{EC}[\mathrm{uS} / \mathrm{cm}]$ & $1158(32)$ & $1845(28)$ & $1213(52)$ & $1191(56)$ & $1520(156)$ & $1354(57)$ & $3690(226)$ \\
\hline Organic substances $[\%]$ & $98.5(1.2)$ & $92.6(1.1)$ & $92.5(0.8)$ & $92.2(0.9)$ & $95.5(1.04)$ & $91.6(1.4)$ & $77.5(1.5)$ \\
\hline $\mathrm{TOC}[\%]$ & 33.5 & 21.6 & 22.6 & 29.1 & 26.1 & 23.4 & 26.1 \\
\hline $\mathrm{N}[\%]$ & 1.82 & 5.51 & 6.52 & 3.45 & 1.44 & 3.38 & 2.38 \\
\hline $\mathrm{C} / \mathrm{N}$ & 18.4 & 3.9 & 3.5 & 8.4 & 11.2 & 6.9 & 11.0 \\
\hline $\mathrm{P}_{2} \mathrm{O}_{5}[\mathrm{~g} / \mathrm{kg} \mathrm{dw}]$ & $4.85(0.12)$ & $4.10(0.24)$ & $5.02(0.31)$ & $4.81(0.80)$ & $2.63(0.32)$ & $4.95(0.07)$ & $4.24(0.46)$ \\
\hline $\mathrm{K}_{2} \mathrm{O}[\mathrm{g} / \mathrm{kg} \mathrm{dw}]$ & 15.6 & 11.7 & 9.30 & 14.9 & 8.94 & 14.0 & 13.0 \\
\hline $\mathrm{CaO}[\mathrm{g} / \mathrm{kg} \mathrm{dw}]$ & 39.9 & 15.0 & 13.9 & 17.5 & 10.0 & 15.4 & 16.2 \\
\hline $\mathrm{MgO}[\mathrm{g} / \mathrm{kg} \mathrm{dw}]$ & 143 & 102 & 79.0 & 93 & 105 & 105 & 136 \\
\hline $\mathrm{Na}{ }_{2} \mathrm{O}[\mathrm{g} / \mathrm{kg} \mathrm{dw}]$ & 1.24 & 2.08 & 4.09 & 0.80 & 1.16 & 0.50 & 56.7 \\
\hline $\mathrm{Zn}[\mathrm{mg} / \mathrm{kg} \mathrm{dw}]$ & 112.1 & 77.60 & 85.86 & 93.0 & 40.76 & 71.47 & 82.01 \\
\hline $\mathrm{Cu}[\mathrm{mg} / \mathrm{kg} \mathrm{dw}]$ & 25.4 & 19.93 & 20.12 & 22.38 & 13.29 & 22.23 & 20.37 \\
\hline $\mathrm{Fe}[\mathrm{mg} / \mathrm{kg} \mathrm{dw}]$ & 176.7 & 158.2 & 175.1 & 179.0 & 92.27 & 166.2 & 158.6 \\
\hline $\mathrm{Cr}[\mathrm{mg} / \mathrm{kg} \mathrm{dw}]$ & 0.853 & 1.55 & 1.63 & 1.78 & 1.41 & 1.80 & 1.05 \\
\hline
\end{tabular}


Mussatto et al. 2011). The fat content in SCG is high and reaches $15 \%$, on average (Mussatto et al. 2011). However, the authors' own studies indicate that there is significant influence of the way the coffee is brewed towards its content in this material. The content of organic carbon in the examined fertilisers is comparable to a good quality manure or cattle slurry (Poulsen et al. 2013; Powlson et al. 2011).

In the examined fertilisers, the high content of nitrogen, which was characterized in detail in the study of Ciesielczuk et al. (Ciesielczuk at al. 2016), is particularly valuable. High content of calcium and magnesium arises from the share of biomass ash. Similarly as in the case of potassium and phosphorus content, their quantities fulfil legal requirements concerning organic fertilisers (Regulation of Minister of Environment 119 pos. 765).

\section{Release of nutrients}

The durability of membrane is the most essential factor, which determines the suitability of a given material needed to make the membrane. The most durable membrane turned out to be vinyl acetate $(\mathrm{OW})$, which was biodegradable in a slight degree and remained non-dissolved until the end of an experiment. The membrane made out of shellac (SZ) was the one which was characterized by medium durability. It became disintegrated after 4 weeks of experiment. From the point of view of durability, the collagen membranes (KK and $\mathrm{KR}$ ) as well as the one from polyvinyl alcohol
(PW), which disintegrated after the first day, were the worst. According to the observed durability of membranes, the fastest release (just after 24 hours) of organic substances occurred in the case of KR and KK membranes (Figure 1). In the case of PW the membrane made out of polyvinyl alcohol, which is water soluble, disintegrated within the 4 days time; however, the amount organic carbon coming from the membrane that got inside the solution was lower due to small thickness of PW membrane. In the remaining kinds of fertilisers, this release was occurring at different rate and depended on the dissolution speed regarding the membrane surrounding the tablet. It is particularly evident in the case of shellac membrane (SZ) and the one from water glass, where organic substances were released only when the solution infiltrated into the tablet.

Organic carbon released from fertiliser tablets in the form of macromolecular residues of cellulose and lignin biodiversity. Dynamics related to the release of nitrogen (Figure 2) is close to the curves recorded for organic carbon. Very high concentrations within the first 24 hours for $\mathrm{KR}$ and $\mathrm{KK}$ indicate the release of protein from membranes. Its disintegration may generate ammonium nitrogen, which may be used by plants, but its significant concentration causes the threat of being washed away outside the root zone. Similar characteristics of changes regarding concentration of nitrogen was recorded in the case of $\mathrm{C}$ type (without membrane); however, the highest values occurred within the 4 days of the experiment. Gelatine, which was released into solution

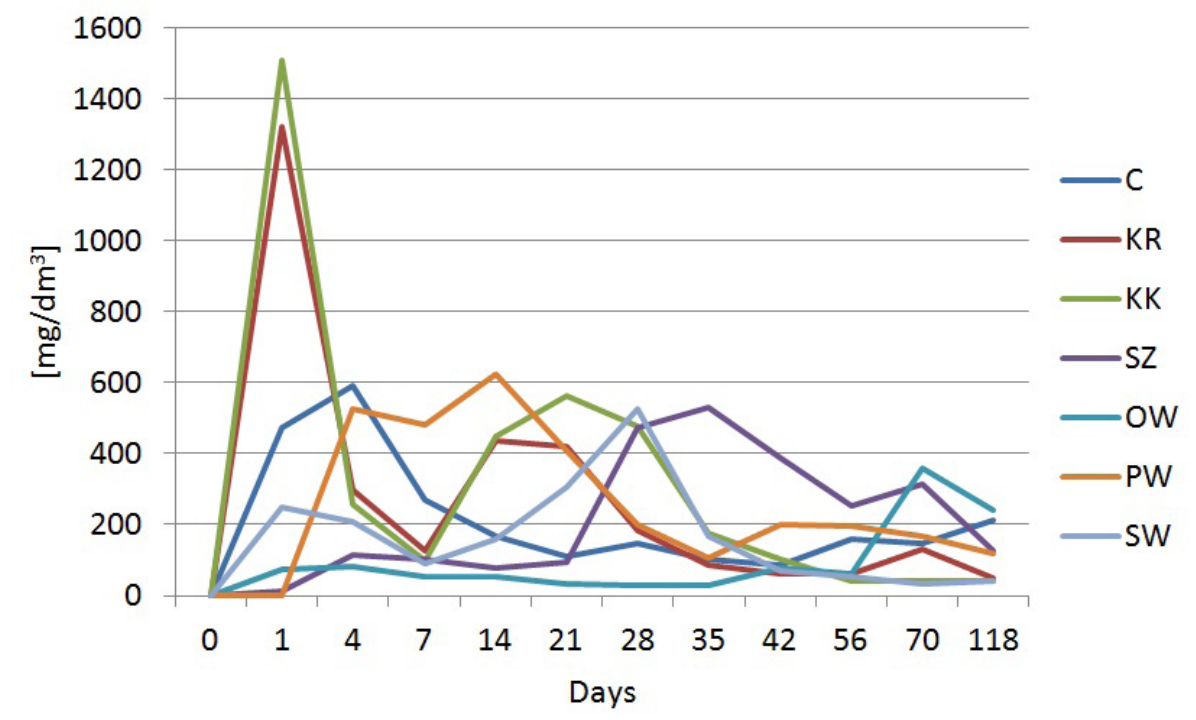

Figure 1. Dynamics of total organic carbon (TOC) release from tested fertilizer tablets in 118 days period at $25^{\circ} \mathrm{C}$ 


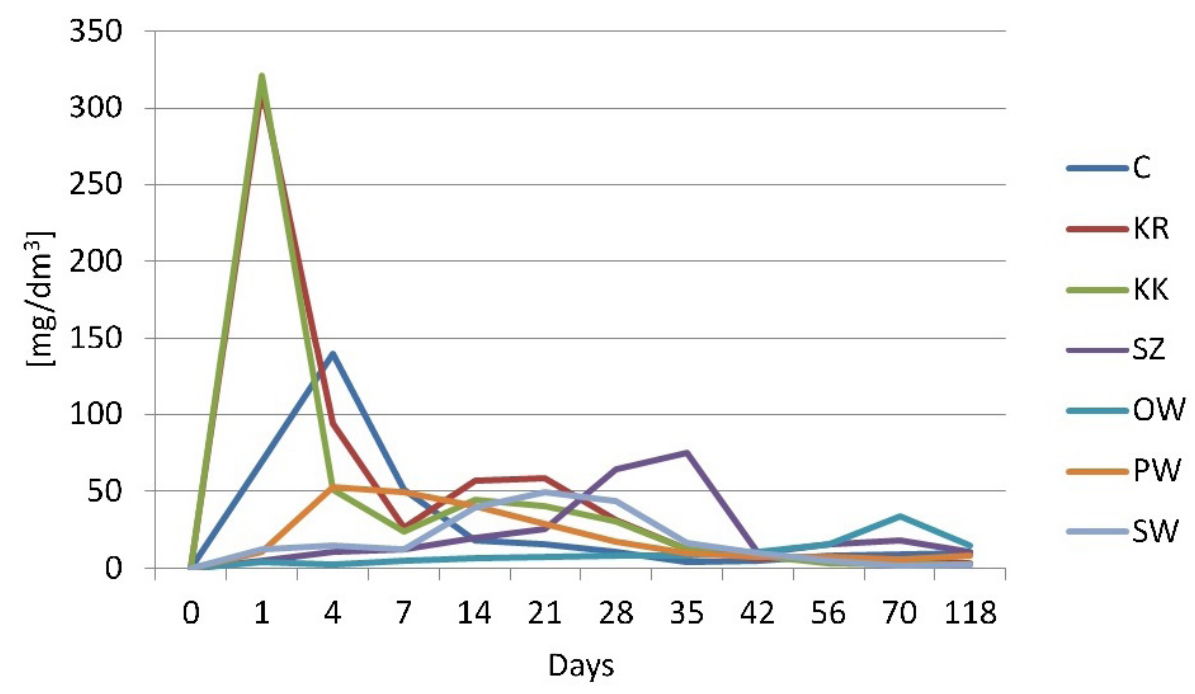

Figure 2. Dynamics of nitrogen release from the tested fertilizer tablets in 118 day period at $25^{\circ} \mathrm{C}$

disintegrated through a microbiological process constituted a probable source of nitrogen. Slow biodegradation of membrane or/and tablet core guarantees low leaching of nitrate ions, which had been described in detail in the study of Ciesielczuk et al. (2016). Leaching of mineral nitrogen was also slow in the experiment with wood chips soaked with ammonium nitrate, in which case only half of nitrogen was washed away from the chips after 32 days (Ahmed et al. 2011). Completely different results were achieved for mineral fertilisers with a controlled release of components in the pot experiment. The concentration maxima were recorded only on $120^{\text {th }}$ day; however, the applied surface, frequency of watering and growing temperature that ranged from 22 up to $30^{\circ} \mathrm{C}$ had a determining influence on the release of nitrogen (Cabrera 1997).

One of the most essential nutrient elements, i.e. phosphorus, was characterized by different characteristics with regard to its release into solution (Figure 3). On the first day, the highest concentrations were recorded for SW, PW and KK. It was connected with disintegration of membrane, which occurred just after the first day of the experiment. Non-durable membranes from water glass and polyvinyl alcohol did not fulfil their roles; therefore, their application is unjustified. Sudden elution of phosphates almost just after the application of fertiliser causes a threat that these ions may be leached inside the soil profile. The remaining tested fertilisers were slowly releasing phosphates and only crack/disintegration of membrane caused the release of phosphorus contained in the biomass ash. Higher concentrations (reach- ing even up to $50 \mathrm{mg} / \mathrm{dm}^{3}$ ) have been recorded in the extracts from mineral fertilisers available in the trade. High concentrations have been maintained for up to 12 months from the time the fertilisers had been applied. (Soti et al. 2015). However, a fertiliser with slow-release components must operate only for 90 days, which is correlated with the time of intensified demand for nutrients in the vegetation period (Cole et al. 2016).

Potassium turned out to be an extremely active ion, because after maxima of concentrations (Figure 4) recorded from the first until fourth day (in which they were comparable to the obtained ones in the case of application of mineral fertiliser tablets), its concentrations decreased significantly. Merely in case of KR type there was a slight growth on the 56 day. (Soti et al. 2015). All tested fertilisers indicated a similar rate with regard to the release of this ion, whereas the highest concentrations were recorded for the $\mathrm{C}$ type, which may be explained by the lack a membrane, and the lowest ones - were recorded for the types of SZ and OW, i.e. in the case of the most durable membranes enabling leaching of biologically available fraction of potassium from the tablet core.

The release of calcium (Figure 5) proceeded in changeable pace with three recorded maxima of concentrations. Particularly interesting was the release of calcium from the OW tablets in the third phase of experiment despite the fact that there was no disintegration of the membrane. One of the highest concentrations was recorded for the PW type - with maximum elution after 7 days and for the SZ type with maximum elution on the $28^{\text {th }}$ day, which was correlated with slow disinte- 


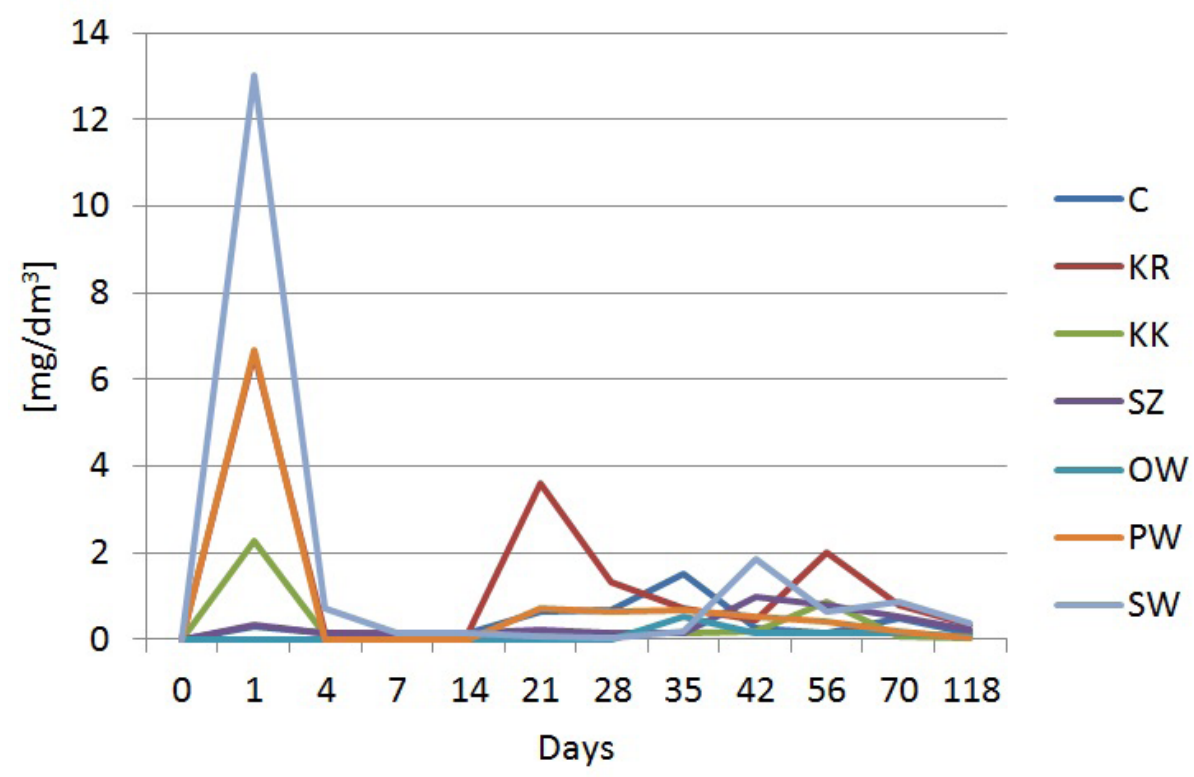

Figure 3. Dynamics of orthophosphate $\left(\mathrm{PO}_{4}^{3-}\right)$ release from the tested fertilizer tablets in 118 days period at $25^{\circ} \mathrm{C}$

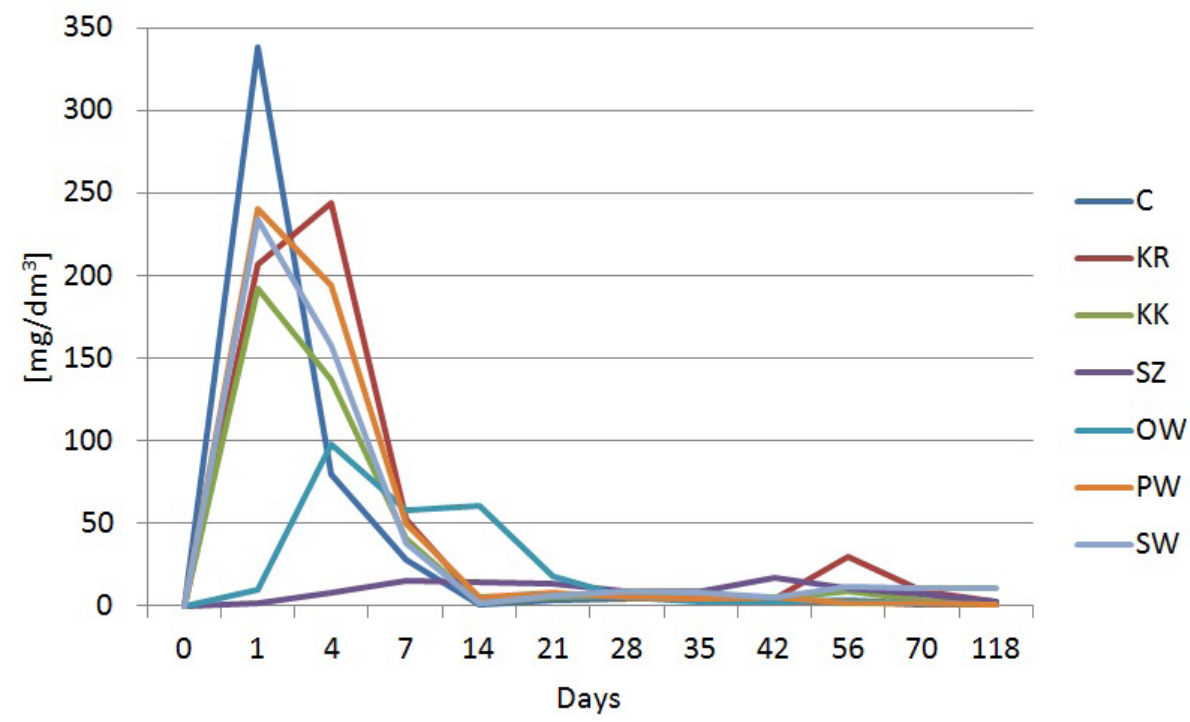

Figure 4. Dynamics of potassium $\left(\mathrm{K}^{+}\right)$release from tested fertilizer tablets in 118 days period at $25^{\circ} \mathrm{C}$

gration of shellac. Long-term release of calcium is important from the point of view of $\mathrm{pH}$ regulation and bioavailability of many chemical elements, which is connected with it. The release of calcium in the elongated time horizon has crucial importance in the regulation of $\mathrm{pH}$ of the surface and in order to ensure appropriate possibilities of development and operation of cell membrane and cell wall of plants (Cole et al. 2106).

The release of magnesium (Figure 6) was strongly differentiated and reached the maxima from 1 up to 7 days for the C, PW and KR types and on the $28^{\text {th }}$ day for the SZ and SW types. The source of magnesium in the tested fertilisers is the ash from biomass and in the experiment it was being released together with calcium; however, without the third maximum in the third phase (42 and 56 day).

The uptake of magnesium through plants may be correlated with the availability of phosphates, which stimulate the growth of roots. Therefore, magnesium available in significant quantities even on the $35^{\text {th }}$ and $42^{\text {nd }}$ day of experiment should constitute an essential source feeding the synthesis process of chlorophyll (Cole et al. 2016).

Maxima of concentrations for sulphate ions were recorded in the first phase of experiment (Figure 7). It indicates that there is its significant 


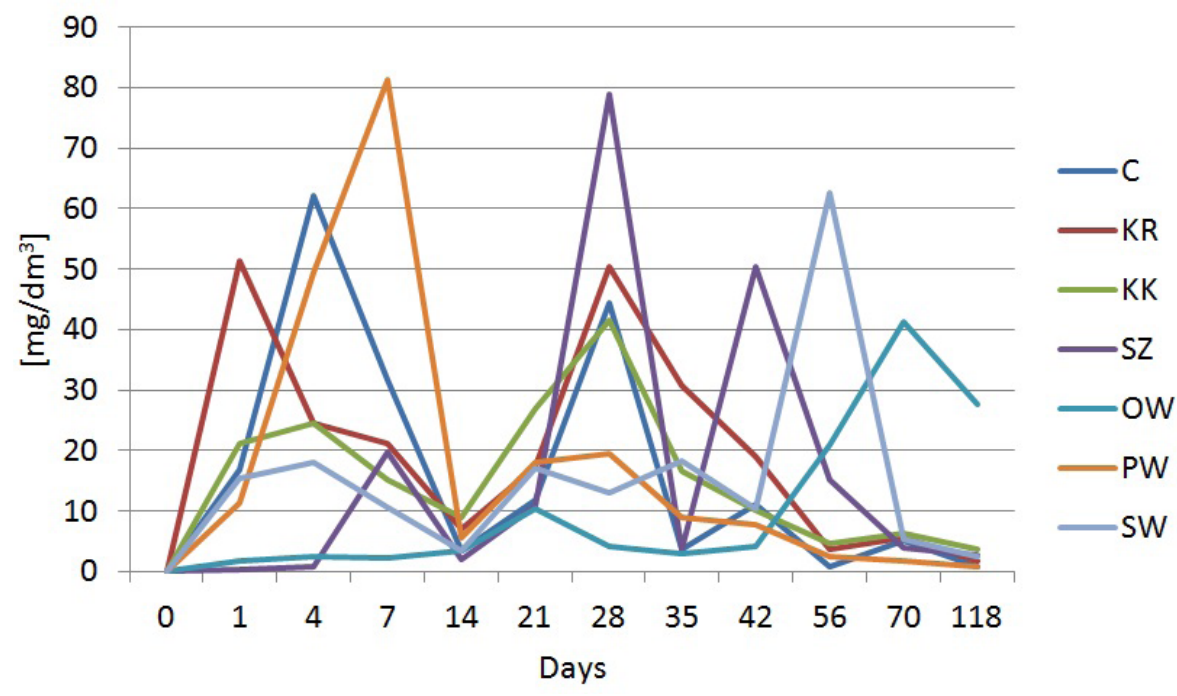

Figure 5. Dynamics of calcium $\left(\mathrm{Ca}^{2+}\right)$ release from tested fertilizer tablets in 118 days period at $25^{\circ} \mathrm{C}$

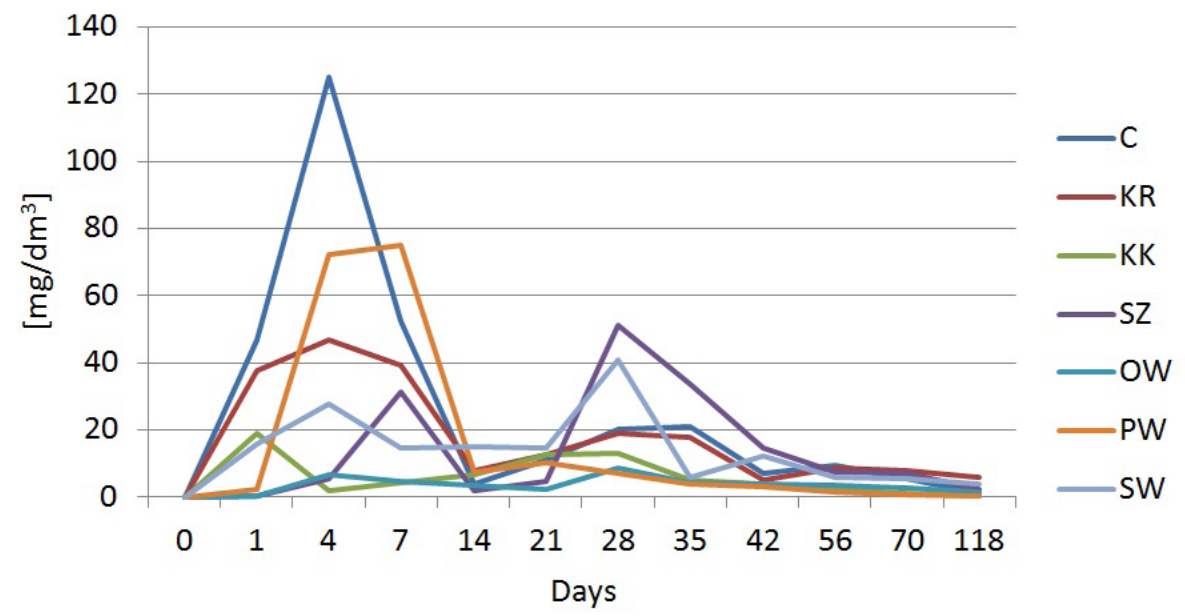

Figure 6. Dynamics of magnesium $\left(\mathrm{Mg}^{2+}\right)$ release from tested fertilizer tablets in 118 days period at $25^{\circ} \mathrm{C}$

participation in the KK, KR, PW and SW membranes; thus, it mostly concerns collagen membranes and slightly less in the polyvinyl acetate and water glass. From the remaining types of tablets, sulphates were being released in significantly smaller volumes, positively correlated with the time elapse. Despite the increased concentrations of these ions recorded in the solution in the first days of experiment, their general amount is not substantial, which does not constitute the threat of excessive salinity or acidification of the surface especially in front of results obtained in experiments with sewage sludge - ash granulates (Mazur et al. 2013, Rosik-Dulewska et al. 2006). The lowest amount of released sulphate ions was recorded for the type of shellac membrane, which definitely confirms that covering of tablets with such barrier is the best of all tested materials.
The low content of heavy metals contained in tested fertilisers, which is sufficient to obtain appropriate growth and development of plants, is worth noting. While it does not constitute a threat for natural environment, which may occur in the case of using composts from the municipal waste or bottom sediments (Lopes et al. 2011, Strzebońska et al. 2015).

\section{CONCLUSIONS}

The tested membranes, which were applied in order to slow the leaching of nutrients from tablet fertilisers, fulfilled their function to a various extent. The most durable membrane made out of vinyl acetate due to its significant stability, to a fundamental extent prevents the 


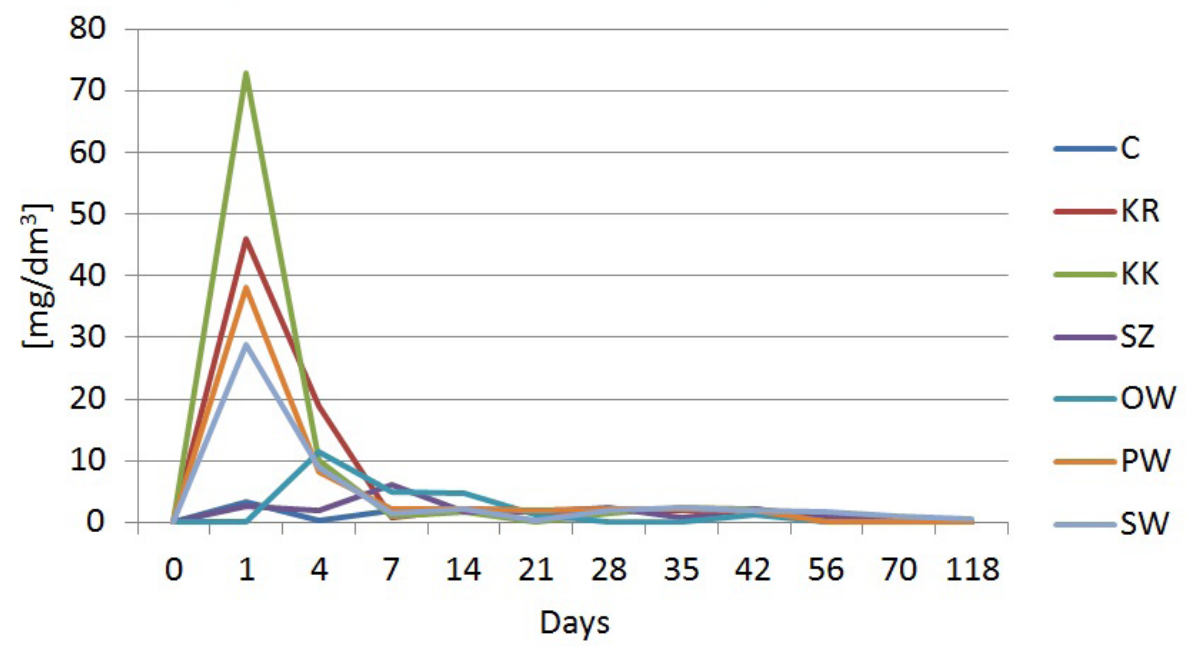

Figure 7. Dynamics of sulphate $\left(\mathrm{SO}_{4}^{2-}\right)$ release from tested fertilizer tablets in 118 days period at $25^{\circ} \mathrm{C}$

release of nutrients from the core of fertiliser tablet. The collagen membranes, as well as polyvinyl alcohol and water glass, which are the most vulnerable to leaching, act for too short in order to effectively slow down the elution process of nutrients into the soil solution. Moreover, water glass causes excessively sudden growth of electrolytic conductivity of solution, which may have an unfavourable impact on the seedlings of sensitive plant species. The best results have been achieved in the case of shellac membrane, which underwent disintegration after about one month from the time it was applied. In addition, the natural character and ease of use predispose this material to be applied as the membrane in the production of organic-mineral tablet fertilisers.

In conclusion, the obtained results indicate that there is a possibility to use shellac as an additive slowing down the release of nutrients from independently manufactured cheap organic-mineral tablet fertilisers, which may be applied not only in the case of organic crops but in broadly defined gardening.

\section{REFERENCES}

1. Ahmed S.A., Kim J.I., Park K.M. 2011. Ammonium nitrate-impregnated woodchips: a slow-release nitrogen fertilizer for plants J Wood Sci 57, 295301, doi: 10.1007/s10086-011-1178-X.

2. Boruszko D. 2011. Research and Evaluation of Fertilizing Value of Composts and Vermicomposts. Annual Set The Environment Protection, 13, 1417-1428.
3. Cabrera R.I. 1997. Comparative evaluation of nitrogen release patternsfrom controlled-release ferilizersby nitrogen leaching analysis. HortScience, 32(4), 669-673.

4. Caetano N.S., Silva V.M.F., Melo A.C., Martins A.A., Mata T.M. 2014.Spent coffee grounds for biodiesel production and other applications. Clean Techn Environ Policy, 16, 1423-1430, doi: 10.1007/s10098-014-0773-0.

5. Cesaro A., Belgiorno V., Guida M. 2015. Compost from organic solid waste: Quality assessment and European regulations for its sustainable use. Resources, Conservation and Recycling 94, 72-79, http://dx.doi.org/10.1016/j.resconrec.2014.11.003.

6. Ciesielczuk T., Rosik-Dulewska Cz., Kochanowska K. 2014. The influence of biomass ash on the migration of heavy metals in the flooded soil profile - model experiment. Archives of Environmental Protection, 40(4), 3-15, doi: 10.2478/aep2014-0034.

7. Ciesielczuk T., Rosik-Dulewska Cz., Szewczyk A, Poluszyńska J. 2016. Dynamika uwalniania azotu z nawozów o powolnym działaniu w eksperymencie laboratoryjnym. Annual Set The Environment Protection, 18, 506-517.

8. Cole J.C., Smith M.W., Penn Ch.J., Cheary B.S., Conaghan K.J. 2016. Nitrogen, phosphorus, calcium, and magnesium applied individuallyor as a slow release or controlled release fertilizer increase growthand yield and affect macronutrient and micronutrient concentrationand content of field-grown tomato plants. Scientia Horticulturae, 211, 420-430 http://dx.doi.org/10.1016/j.scienta.2016.09.028.

9. Demeyer A., Voundi-Nkana J.C., Verloo M.G. 2001. Characteristics of wood ash and in uence on soil properties and nutrient uptake: an overview. Bioresource Technology 77, 287-295. 
10. Dz.U. Nr 119, poz. 765. Rozporządzenie Ministra Rolnictwa I Rozwoju Wsi z dnia 18 czerwca 2008, w sprawie wykonywania niektórych przepisów ustawy o nawozach i nawożeniu.

11. Lopes C., Herva M., Franco-Uría A., Roca E. 2011. Inventory of heavy metal content in organic waste applied as fertilizer in agriculture: evaluating the risk of transfer into the food chain. Environ Sci Pollut Res, 18, 918-939, doi: 10.1007/ s11356-011-0444-1.

12. Ludwig B., Geisseler D., Michel K., Joergensen R.G., Schulz E., Merbach I., Raupp J., Rauber R., $\mathrm{Hu}$ K., Niu L., Liu X. 2011. Effects of fertilization and soil management on crop yields and carbon stabilization in soils. A review. Agron. Sustain. Dev., 31, 361-372, doi: 10.1051/agro/2010030.

13. Mazur Z., Radziemska M., Tomaszewska Z., Świątkowski Ł. 2013. Effect of sodium chloride salinization on the seed germination of selected vegetable plants. Scientific Review - Engineering and Environmental Sciences, 62, 444-453.

14. Mussatto S.I., Machado E.M.S., Martins S., Teixeira J.A. 2011. Production, Composition, and Application of Coffee and Its Industrial Residues. Food Bioprocess Technol, 4, 661-672, doi: 10.1007/ s11947-011-0565-z.

15. Poulsen P.H.B., Magid J., Luxhøi J., de Neergaard A. 2013. Effects of fertilization with urban and agricultural organic wastes in a field trial - Waste imprint on soil microbial activity. Soil Biology \& Biochemistry, 57, 794-802, doi: 10.1016/j.soilbio.2012.02.031.

16. Powlson D.S., Gregory P.J., Whalley W.R., Quinton J.N., Hopkins D.W., Whitmore A.P., Hirsch P.R., Goulding K.W.T. 2011. Soil management in relation to sustainable agriculture and ecosystem services. Food Policy;36, 72-87, doi: 10.1016/j. foodpol.2010.11.025

17. Pujol D., Liu C., Gominho J., Olivella M.À., Fiol N., Villaescusa I., Pereira H. 2013. The chemical composition of exhausted coffee waste. Industrial Crops and Products, 50, 423-429, http://dx.doi. org/10.1016/j.indcrop.2013.07.056.

18. Rosik-Dulewska Cz., Glowala K., Karwaczyńska U., Robak J. 2008. Elution of heavy metals from granulates produced from minicipal sewage deposits and fly-ash of hard and Brown coal in the aspect of recycling for fertilization purposes. Archives of Environmental Protection, 34, (2), 63-71.

19. Rosik-Dulewska Cz., Głowala K., Karwaczyńska U., Szydło E. 2006. The Mobility of Chosen Pollutants from Ash-Sludge Mixtures. Polish J. of Environ. Stud., 15(6), 895-904.

20. Soti P., Fleurissaint A., Reed S., Jayachandran K. 2015. Effects of Control Release Fertilizers on Nutrient Leaching, Palm Growth and Production Cost. Agriculture, 5, 1135-1145, doi: 10.3390/agriculture 5041135

21. Statistical Yearbook of Environmental Protection 2017. Central Statistical Office, 331-332

22. Strzebońska M., Kostka A., Helios-Rybicka E., Jarosz-Krzemińska E. 2015. Effect of Flooding on Heavy Metals. Contamination of Vistula Floodplain Sediments in Cracow; Historical Mining and Smelting as the Most Important Source of Pollution. Polish J. of Environ. Stud., 34, (3), 1317-1326, doi: 10.15244/pjoes/33202

23. Xiao R., Chen X., Wang F., Yu G. 2011. The physicochemical properties of different biomass ashes at different ashing temperature. Renewable Energy, $36,244-249$. 